\title{
How Have the Subjective Poverty Lines and The Perceived Consequences of Poverty Changed During the Pandemic in Minnesota?
}

\author{
Eszter Siposne Nandori \\ University of Miskolc, Miskolc, Hungary \\ stsneeuni-miskolc.hu
}

\section{ABSTRACT}

I examine how the subjective interpretation of poverty has been affected by the COVID-19 pandemic and the related economic downturn in St. Louis County, Minnesota, using comparative data from a data collection conducted before and during the pandemic. The data collection using cultural domain analysis asked information about the informants' beliefs about poverty. I find that the importance of the main perceived consequences of poverty did not change significantly during the pandemic. In both Surveys, consequences related to material needs made up an important part of the items. A remarkable difference, however, is that the problem of perpetuated poverty is perceived to be more important during the pandemic. The subjective poverty lines did not change significantly during the pandemic either. The income level below which most of the people can be considered poor is between \$ 14-15 per capita hourly net income on average. Three friends who are ready and able to help were enough to avoid poverty. Most of the large families are perceived to be poor when they bring up at least three children, while it was two children right before the pandemic. As for educational level, the poverty threshold was increased from 11 th grade to high school graduate. It implies that if the individual did not graduate from high school, (s)he is more likely to become poor than before the pandemic.

Keywords: COVID-19, Interpretation of Poverty, Poverty Threshold, St. Louis County, Systematic Data Collection

Cite this article as: Nandori, E. S. (2021). How Have the Subjective Poverty Lines and The Perceived Consequences of Poverty Changed During the Pandemic in Minnesota?. European Journal of Economics, 1(1), 14-21. https://doi.org/10.33422/eje.v1i1.43

\section{Introduction}

The paper examines how the subjective interpretation of poverty changed during 2020 in St. Louis County, Minnesota. The examined period includes the COVID-19 pandemic and the related economic and social downturn. The research work aims at revealing the changes in the interpretation of poverty that happened during these unprecedented times, focusing on the changes of subjective poverty lines and the perceived consequences of poverty. This question is relevant because unusual social and/or economic strains like the COVID-19 pandemic and the related social and economic downturn can temporarily modify the public perception of poverty (Hunt, 1996, Kluegel \& Smith, 1986, Lee et al., 1990, Marquis, 2020).

Public perception of poverty was examined in St. Louis County, Minnesota, at the beginning of 2020 (before COVID-19 pandemic) with cultural domain analysis and the methods of systematic data collection. In summer 2020, I repeated the data collection to reveal whether the pandemic has been associated with any effect on the subjective interpretation of poverty in 
Minnesota where racial groups experience multiple disadvantages in spite of the overall high quality of life and well-being in the state.

The paper first describes the definition and measurement of subjective poverty as well as poverty in Minnesota, with special regard to the case of its northeastern part. A review of the applied methodology is then presented. Next, the Results section describes the main characteristics and changes of the subjective poverty lines and of the perceived consequences of poverty.

\section{Subjective Poverty}

Poverty is usually measured with objective (absolute and relative) measures. Absolute poverty concept assumes that basic necessities of life can be defined regardless of space and time. Individuals are considered poor if they are not able to satisfy the basic human needs. Using this definition, comparison of poverty is possible across countries or over time. Relative poverty concept defines the poor as individuals whose income level falls below some relative poverty threshold, like the $60 \%$ of the equalized median income level. Another relative poverty threshold can be an income level below which the financial position of a certain part (one tenth or one fifth) of the population falls (Hegedüs \& Monostori, 2005).

Subjective poverty is less often used in spite of being beneficial to identify poverty and to work out effective and successful strategies towards the eradication of poverty (Wang et al. 2020). Besides referring to the individuals' own opinions of whether their material situations are below the level they consider acceptable (Marks, 2007), subjective poverty concept is also a possible way to examine what people consider necessary to avoid poverty in general.

Subjective poverty can be measured with questionnaire surveys. Three main types of questionnaires are distinguished in the literature. The Income Evaluation Question was designed by Van Praag $(1968,1982)$ to collect data on subjective well-being and to analyze subjective poverty in European countries. Besides, Goedhart et. al. (1977) developed the Minimum Income Question and measured subjective poverty in the United States (Danzinger et al., 1984, Colasanto et al., 1984). Garner and Short (2005) modified Minimum Income Question and developed Minimum Spending Question to study subjective poverty in the United States. The Social Policy Question, the third type of questionnaire to measure subjective poverty, was elaborated by Deleeck and Van den Bosch (1992).

\section{Poverty in Minnesota}

The so-called Minnesota paradox refers to the troubling inconsistency between the overall high values of the different measures of economic and social well-being and the large racial differences in all of these measures, which exists in spite of the relatively small minority population. Besides economic and social measures, racial disparities can also be detected in health outcomes like rate of lower birthweight births and the infant mortality rate (Fig. 1.) (Nanney et al., 2019). Moreover, there are troubling disparities among racial groups in their education level, median income level, and poverty rate (Mattessich, 2015). The most recent estimates indicate that around 30\% of people that identify as American Indian or Alaska Native (34\%) or as Black or African American (27\%) are in poverty, while the poverty rate is significantly lower for other racial/ethnic groups (7\% for White and 19\% for Hispanic ethnicity). Besides racial disparities, poverty is also related to health, and to educational attainment (People in poverty in Minnesota). 


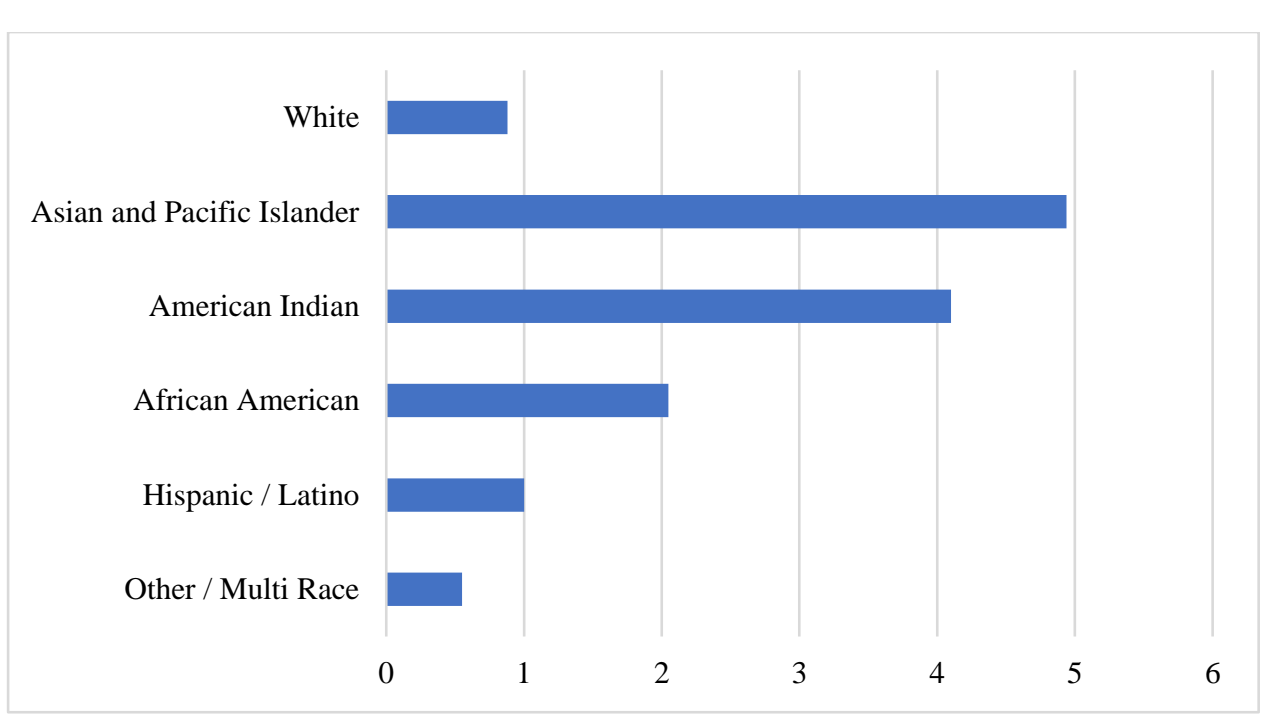

Figure 1. Disparity ratios for mortality rate for children ages 5-14 in Minnesota Source. Nanney et al. p. 6.

Northeastern Minnesota, including St. Louis County, has vibrant mining industry, woodproducts industry, and tourism. In spite of the success of these industrial sectors, however, the regional poverty rate was close to $17 \%$ in 2014 , which is almost twice the statewide average (Brown, 2015; Bergstrom, 2019). The copper-nickel and precious metals (CNPM) in St. Louis County, is assumed to be the world's largest undeveloped deposit. Some experts believe that the extraction will create hundreds of jobs and will decrease poverty, while others argue that mining will impair the region's development. Only the upcoming decades will determine how the region's economy, society, and environment will be affected with CNPM mining and whether it can help the alleviation of poverty (Bergstrom, 2019).

\section{Materials and Methods}

The study aims to identify how subjective poverty changed in St. Louis County, Minnesota, due to the COVID-19 pandemic and the related economic and social downturn. It focuses on the change in the subjective poverty thresholds and the perception of the consequences of poverty.

I used cultural domain analysis to trace the underlying conceptual content and structure of the domain of interest. The qualitative research techniques of systematic data collection related to cultural consensus analysis are used to define perceived consequences of poverty. These methods were developed more than 30 years ago by anthropologist Susan Weller and mathematician Kimball Romney (Romney and Weller 1988).

Details of the pre-pandemic data collection (carried out in February and March of 2020) are described in Siposné Nándori (2021). The second data collection was realized in the summer (July and August of 2020)

I first conducted cognitive anthropological cultural domain analysis, based on free-listing (Johnson et al., 2002, Romney \& Weller, 1988), on the individuals' perceptions of poverty in general and the consequences of poverty, collected from a small sample of the population of St. Louis County, Minnesota. Then I linked cultural domain analysis and pile-sort interviews, which is standard within the framework of consensus theory (Snodgrass et al., 2019), and I asked a second group of individuals (separately, not as a group) to sort the consequences of poverty from the free listing creating a total rank order of the consequences. Besides, I asked the individuals of the second group to find the perceived precise meaning of poverty thresholds, using rating scales (refer to Fig. 2). 
1. Low-income level is considered to be an indicator of poverty. What is the per capita hourly net income below which the bulk of the people can be considered poor?

\begin{tabular}{|l|l|l|l|l|l|l|l|l|l|}
\hline$<\$ 10$ & $\$ 10-$ & $\$ 12.5-$ & $\$ 15-$ & $\$ 17.5-$ & $\$ 20-$ & $\$ 22.5-$ & $\$ 25-$ & $\$ 27.5-$ & $\$ 30-$ \\
& 12.5 & 15 & 17.5 & 20 & 22.5 & 25 & 27.5 & 30 & \\
\hline
\end{tabular}

2. Many people believe that the lack of connections can make people poor. What do you think about it? Most people are poor if they can count on

\begin{tabular}{|c|c|c|c|c|c|c|}
\hline 0 & 1 or 2 & 3 or 4 & 5 or 6 & 7 or 8 & 9 or 10 & 11 or more \\
\hline
\end{tabular}

3. People bringing up many children often find it difficult to make ends meet. How many children can cause such problems in general?

\begin{tabular}{|c|l|l|l|l|l|}
\hline 1 & 2 & 3 & 4 & 5 & 6 or more \\
\hline
\end{tabular}

4. What is the educational level below which the bulk of the people are considered to be poor?

\begin{tabular}{|c|c|c|c|c|c|c|}
\hline none & $\begin{array}{c}1^{\text {st }}-4^{\text {th }} \\
\text { grade }\end{array}$ & $\begin{array}{c}5^{\text {th }}-6^{\text {th }} \\
\text { grade }\end{array}$ & $\begin{array}{c}7^{\text {th }}-8^{\text {th }} \\
\text { grade }\end{array}$ & $\begin{array}{c}9^{\text {th }}-10^{\text {th }} \\
\text { grade }\end{array}$ & $11^{\text {th }}$ grade & $\begin{array}{c}\text { high } \\
\text { school } \\
\text { graduate }\end{array}$ \\
\hline $\begin{array}{c}\text { some } \\
\text { college, } \\
\text { no } \\
\text { degree }\end{array}$ & $\begin{array}{c}\text { Associate's } \\
\text { degree, } \\
\text { occupational }\end{array}$ & $\begin{array}{c}\text { Associate's } \\
\text { degree, } \\
\text { academic }\end{array}$ & $\begin{array}{c}\text { Bachelor's } \\
\text { degree }\end{array}$ & $\begin{array}{c}\text { Master's } \\
\text { degree }\end{array}$ & $\begin{array}{c}\text { Professional } \\
\text { degree }\end{array}$ & $\begin{array}{c}\text { Doctoral } \\
\text { degree }\end{array}$ \\
\hline
\end{tabular}

Figure 2. Questionnaire for rating scales

Source. own compilation

The sample was drawn using multistage cluster sampling, respecting the decomposition of the County's population (refer to Tab. 1)

Table 1.

Sample decomposition based on the distribution of the population in St Louis County, Minnesota

\begin{tabular}{lccccc}
\hline & $\begin{array}{c}\text { Population } \\
\mathbf{( 2 0 1 9 )}\end{array}$ & \multicolumn{2}{c}{ Sample size for free listing } & \multicolumn{2}{c}{ Sample size for pile-sort } \\
Survey 1 & Survey 2 & Survey 1 & Survey 2 \\
\hline Duluth & 85,915 & 17 & 13 & 9 & 6 \\
Other part of the & 113,155 & 23 & 18 & 12 & 9 \\
county & 199,070 & 40 & 31 & 21 & 15 \\
Total & & & & \\
\hline
\end{tabular}

Source. own compilation based on United States Census Bureau data

\section{Results}

The most often mentioned consequences of poverty (Fig. 2), like "homelessness", "malnutrition", or "poor health", express the inability to satisfy the basic human needs. Besides, "crime", "addiction", and "no health insurance" are also mentioned in both Surveys. The items "perpetuated poverty" and "become stuck in" were mentioned only in Survey 2 in relation to poverty. This draws the attention to generational poverty and the higher chance of living in poverty if the parents are also poor. Other items that were first mentioned during the pandemic are "isolated" and "shorter life expectancy". 


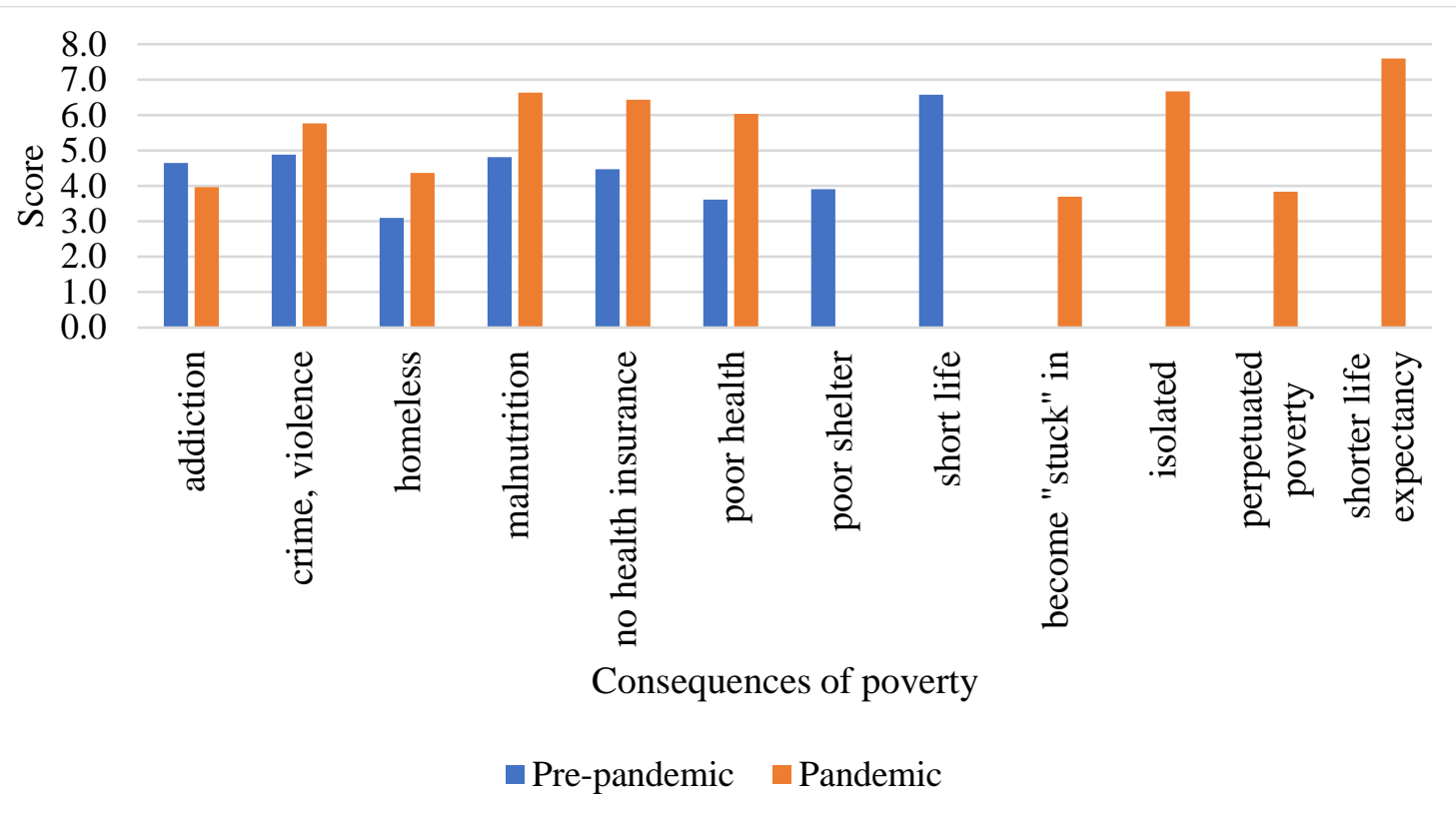

Figure 2. Perceived consequences of poverty and their importance before and during the pandemic Source. own compilation

The relative importance of the consequences of poverty before and during the pandemic can be compared by first expressing their ranking in percentage of the total number of ranked items. Comparison is possible in the case of six items. After that, change in their relative ranking (relative mean) can be examined with statistical tests ( $\mathrm{F}$ test for the equality of variances and $\mathrm{t}$ test for the equality of means) to reveal significant differences. The results (Tab. 2) highlight that at the 5\% significance level, no changes were significant. Some slight changes, however, can be detected. Distinction is sharpest for the relative position of "addiction", which was considered more often related to poverty during the pandemic than before. Besides, "poor health" was considered less often a consequence of poverty in Survey 2.

Table 2.

Change in the ranking of potential consequences of poverty due to the pandemic

\begin{tabular}{lcccc}
\hline Consequence of poverty & \multirow{2}{*}{ F (sig) } & $\mathbf{t}(\mathbf{s i g})$ & \multicolumn{2}{c}{ Mean (in percentage) } \\
Survey 1 & Survey 2 \\
\hline Addiction & $4.438(0.043)$ & $1.816(0.078)$ & 58.04 & 39.67 \\
Crime & $0.278(0.601)$ & $0.356(0.724)$ & 61.01 & 57.67 \\
Homelessness & $0.195(0.662)$ & $-0.572(0.571)$ & 38.69 & 43.67 \\
No health insurance & $0.000(0.987)$ & $-0.840(0.407)$ & 55.95 & 64.33 \\
Malnutrition & $0.002(0.966)$ & $-0.827(0.414)$ & 60.12 & 66.33 \\
Poor health & $2.345(0.135)$ & $-1.831(0.076)$ & 45.24 & 60.33 \\
\hline
\end{tabular}

Source. own compilation

Based on the results of the rating scales, the perceived meaning of the items of interest can be found with the use of estimation. To do so, 0.95 confidence level is applied (Tab. 3). The subjective poverty line in per capita hourly net income was between $\$ 13$ and $\$ 17$ in Survey 1 and between $\$ 13$ and $\$ 16$ in Survey 2 . The mean slightly changed and the standard deviation became smaller. In the case of connections, the bulk of the people were considered poor when they could count on fewer than three persons in both surveys. The presence of three friends who are ready and able to help the individual could protect him / her from impoverishment. The small increase (from 2.75 to 2.93 ) does not seem to be remarkable. 
Table 3.

Results of the rating scales

\begin{tabular}{lcccccc}
\hline \multicolumn{1}{c}{ Item } & Year & $\begin{array}{c}\text { Sample } \\
\text { Size }\end{array}$ & Mean & SD & \multicolumn{2}{c}{ 95\% confidence interval } \\
lower & upper \\
\hline Income level & Survey 1 & 21 & 14.68 & 4.16 & 12.78 & 16.57 \\
Number of & Survey 2 & 15 & 14.25 & 3.02 & 12.58 & 15.92 \\
connections & Survey 1 & 21 & 2.75 & 2.02 & 1.81 & 3.69 \\
Number of & Survey 2 & 15 & 2.93 & 2.78 & 1.40 & 4.47 \\
children & Survey 1 & 21 & 2.05 & 1.32 & 1.43 & 2.67 \\
Education level & Survey 2 & 15 & 2.73 & 1.44 & 1.94 & 3.53 \\
& Survey 1 & 21 & 6.00 & 2.21 & 4.99 & 7.01 \\
\hline
\end{tabular}

Source. own compilation

In the case of large families, people think that the majority of them was considered poor because of having many children when they bring up more than one to three children in Survey 1. This threshold was increased to two to four children by the summer 2020. It implies that having at least three children is needed to have a great probability of becoming poor. As for educational level, the poverty threshold was increased from 11th grade (signed with 6) to high school graduate (signed with 7). If you have not graduate from high school, now you are more likely to become poor than before the pandemic. To test weather the changes are significant or not, statistical tests ( $\mathrm{F}$ and $\mathrm{t}$ tests) were carried out.

The comparison of the rating scales between the two Surveys (Tab. 4) highlights that there were no significant changes at the 5\% significance level in 2020.

Table 4.

Change in the subjective poverty thresholds due to the pandemic

\begin{tabular}{lcc}
\multicolumn{1}{c}{ Poverty threshold } & F (sig) & t (sig) \\
\hline Income level (USD) & $1.229(0.275)$ & $0.339(0.736)$ \\
Number of friends & $0.017(0.896)$ & $-0.227(0.822)$ \\
Number of children & $0.035(0.853)$ & $-1.461(0.153)$ \\
Education level & $3.712(0.062)$ & $-1.237(0.225)$ \\
\hline
\end{tabular}

Source. own compilation

\section{Discussion}

Subjective poverty in St Louis County, Minnesota, was examined with cultural domain analysis before and during the COVID-19 pandemic to reveal whether the pandemic caused any changes in the subjective interpretation of poverty. Data collections were carried out before the pandemic (at the beginning of 2020) and during it (in the summer 2020)

The research results revealed that in spite of the pandemic and the related economic and social problems, the importance of the main perceived consequences of poverty did not change. In both Surveys, consequences related to material needs ("homelessness", "malnutrition", or "poor health") made up an important part of the items. A remarkable difference is that the problem of perpetuated poverty has become more important. Once an individual gets poor, public perceive it to be more difficult to get out of poverty. Moreover, "isolated" was also mentioned as a consequence of poverty in Survey 2, implying that probably because of the lockdown and the requirement to practice social distancing associated with the pandemic, more people may have felt isolated.

The subjective poverty lines have not changed significantly during the pandemic. The income level below which most of the people can be considered poor is between $\$ 14-15$ per capita hourly net income on average. The number of friends or family members necessary to protect individuals from impoverishment has not changed significantly either. Three friends who are 
ready and able to help were enough to avoid poverty. Most of the large families are perceived to be poor when they bring up at least three children. This poverty line was two children before the pandemic. As for educational level, the poverty threshold were increased from 11th grade to high school graduate. If the individual has not graduate from high school, (s)he is more likely to become poor than before the pandemic.

\section{Acknowledgment}

This research was supported by the project nr. EFOP-3.6.2-16-2017-00007, titled Aspects on the development of intelligent, sustainable and inclusive society: social, technological, innovation networks in employment and digital economy. The project has been supported by the European Union, co-financed by the European Social Fund and the budget of Hungary.

\section{References}

Bergstrom, R. D. (2019). Community development in the face of resource extraction in northern Minnesota, USA. The Extractive Industries and Society, 6(3), 831-841. https://doi.org/10.1016/j.exis.2019.06.007

Brown A. (2015): Pedaling New Hope for an Old Mining Town. The Daily Yonder

Colasanto, D., Kapteyn, A., \& van der Gaag, J. (1984). Two Subjective Definitions of Poverty: Results From the Wisconsin Basic Needs Study, The Journal of Human Resources, 19(1), 127-138. https://doi.org/10.2307/145421

Danziger, S., van der Gaag J., Taussig, M. K. \& Smolensky E. (1984). The Direct Measurement of Welfare Levels: How Much Does It Cost to Make Ends Meet? The Review of Economics and Statistics. MIT Press, vol. 66, no. 3, pp. 500-505. https://doi.org/10.2307/1925010

Deleeck, H. \& Van den Bosch, K. (1992). Poverty and adequacy of social security in Europe: A comparative analysis, Journal of European Social Policy, 2(2), 107-120. https://doi.org/ $\underline{10.1177 / 095892879200200203}$

Goedhart, T., Halberstadt, V., Kapteyn, A. \& Van Praag B. M. (1977). The poverty line: Concept and measurement. The Journal of Human Resources, 12(12), 503-520. https://doi.org/10.2307/145372

Hegedüs, P. \& Monostori, J. (2005). A Szegénység és a Társadalmi Kirekesztődés Méröszámai 2005 (Indicators of Poverty and Social Exclusion), Elméleti megalapozás. Budapest: KSH Népességtudományi Kutató Intézet.

Hunt, M. (1996). The individual, society, or both? A comparison of Black, Latino and White beliefs about the causes of poverty. Social Forces, 75, 293-322. https://doi.org/10.1093 $\underline{\text { sff/75.1.293 }}$

Johnson, J. C., Weller, S. C. \& Brewer, D. D. (2002). Systematic Data Collection and Analysis. Field Methods, 14(1), 3-5

Kluegel, J. R., \& Smith, E. R. (1986). Social institutions and social change. Beliefs about inequality: Americans' views of what is and what ought to be. Aldine de Gruyter. https://doi.org/10.1093/sw/33.1.85-b

Lee, B. A., Jones, S. H., \& Lewis, D. W. (1990). Public Beliefs About the Causes of Homelessness. Social Forces, 69(1), 253-265. https://doi.org/10.2307/2579617

Marks, G. N. (2007). Income poverty, subjective poverty and financial stress. Social Policy Research Paper, no. 29. Australian Government. Department of Families, Community Services and Indigenous Affairs. 
Marquis L. (2020). Lay explanations for poverty: A multilevel analysis of European public opinion (1976 - 2014). The European Social Model under Pressure. pp 253-275. https://doi.org/10.1007/978-3-658-27043-8_15

Mattessich P. (2015). The Minnesota Paradox. Retrieved from https://www.mncompass.org/ trends/insights/2015-03-01-minnesota-paradox.

Nanney, M.S., Myers, S.L. Jr., Xu, M., Kent, K., Durfee, T., \& Allen, M.L. (2019). The Economic Benefits of Reducing Racial Disparities in Health: The Case of Minnesota. International Journal of Environmental Research and Public Health, 16(5), 742. https://doi.org/10.3390/ijerph16050742

People in poverty in Minnesota. Retrieved from https://data.web.health.state.mn.us/poverty basic

Romney, A. K. \& Weller, S. C. (1988). Systematic data collection (Vol. 10). Sage Publications, Incorporated.

Siposné Nándori, E. (2021). Individualism or Structuralism-Differences in the Public Perception of Poverty between the United States and East-Central Europe. Journal of Poverty. Under publication. https://doi.org/10.1080/10875549.2021.1910892

Snodgrass, J.G., Dengah, H.J.F., Polzer E, \& Else, R. (2019) Intensive online videogame involvement: A new global idiom of wellness and distress. Transcultural Psychiatry, 56(4), 748-774. https://doi.org/10.1177/1363461519844356

Van Praag, B. M. (1968). Individual welfare functions and consumer behavior: A theory of rational irrationality. Amsterdam: North-Holland Pub. Co.

Van Praag, B. M., Hagenaars, A. J.M. \& van Weeren, H. (1982). Poverty in Europe, The Review of Income and Wealth, 28(3), 345-359

Wang, H., Zhao, Q., Bai, Y., Zhang, L., \& Yu, X. (2020). Poverty and Subjective Poverty in Rural China, Social Indicators Research, 150, 219-242. https://doi.org/10.1007/s11205020-02303-0 